The eGFR was calculated by CKD-EPI, MDRD4-IDMS and Cockcroft-Gault. Patients with serum creatinine below $0.4 \mathrm{mg} / \mathrm{dl}$ were excluded.

CKD-EPI was used as a reference formula to assess the concordance between the different methods of estimating, classifying patients in 3 eGFR groups according to the IV dexketoprofen SmPC: $<50 \mathrm{~mL} / \mathrm{min} / 1.73 \mathrm{~m}^{2}, 50-80 \mathrm{~mL} / \mathrm{min} / 1.73 \mathrm{~m}^{2}$ and $>80 \mathrm{~mL} / \mathrm{min} /$ $1.73 \mathrm{~m}^{2}$.

Results The study included 1946 patients - 54.3\% men, 45.7\% women - from a total population of 2052 admissions; mean age of 59.8 years (range $17-103$ ). The mean serum creatinine concentration was $0.84 \mathrm{mg} / \mathrm{dL} \pm 0.43$ and mean eGFR, according to CKDEPI, $83.05 \pm 26.17 \mathrm{~mL} / \mathrm{min} / 1.73 \mathrm{~m}^{2}$.

The following results of non-concordance were found by comparing these formulas to estimate renal function:

- CKD-EPI vs. MDRD4-IDMS: $4.3 \%$ in eGFR $<50 \mathrm{~mL} /$ $\mathrm{min} / 1.73 \mathrm{~m}^{2}$ group, $23.2 \%$ in the eGFR $50-80 \mathrm{~mL} / \mathrm{min} / 1.73$ $\mathrm{m}^{2}$ and $18.9 \%$ in eGFR $>80 \mathrm{~mL} / \mathrm{min} / 1.73 \mathrm{~m}^{2}$.

- CKD-EPI vs. CG: $2.8 \%$ in eGFR $<50 \mathrm{~mL} / \mathrm{min} / 1.73 \mathrm{~m}^{2}$ group, $10.5 \%$ in eGFR $50-80 \mathrm{~mL} / \mathrm{min} / 1.73 \mathrm{~m}^{2}$ and $7.8 \%$ in eGFR $>$ $80 \mathrm{~mL} / \mathrm{min} / 1.73 \mathrm{~m}^{2}$.

- MDRD4-IDMS vs. CG: $4.5 \%$ in the group of eGFR $<50 \mathrm{ml} /$ min, $21.4 \%$ in group eGFR $50-80 \mathrm{~mL} / \mathrm{min}$ and $17.1 \%$ in the group of eGFR $>80 \mathrm{ml} / \mathrm{min}$.

Conclusions A great difference was found in the estimates of renal function between the three methods used - CKD-EPI, MDRD4IDMS and CG - in the three eGFR functional categories $-<50$, $50-80$ and $>80 \mathrm{~mL} / \mathrm{min} / 1.73 \mathrm{~m}^{2}$ - ranging between $2.8 \%$ and $23.2 \%$.

These results are relevant in clinical practise because the functional category determines the non-use or limited dose of dexketoprofen IV for each patient.

No conflict of interest.

\section{PHC-025 SINGLE NUCLEOTIDE POLYMORPHISMS ASSOCIATED WITH ADVERSE EVENTS IN TAXANE-TREATED BREAST CANCER PATIENTS}

doi:10.1136/ejhpharm-2013-000276.370

${ }^{1} \mathrm{~V}$ Bosó-Ribelles, ${ }^{1} \mathrm{MJ}$ Herrero-Cervera, ${ }^{2} \mathrm{~A}$ Santaballa-Beltran, ${ }^{2} \mathrm{~L}$ Palomar-Abad, ${ }^{2} \mathrm{H}$ de la Cueva-Sapiña, ${ }^{2} \mathrm{~J}$ Montalar-Salcedo, ${ }^{3}$ SF Aliño-Pellicer, ${ }^{1} \mathrm{JL}$ Poveda-Andrés. ${ }^{1}$ Hospital Universitario La Fe, Pharmacy, Valencia, Spain; ${ }^{2}$ Hospital Universitario La Fe, Medical Oncology, Valencia, Spain; 'Universidad de Valencia, Pharmacology Department. Facultad de Medicina, Valencia, Spain

Background Inter-individual differences in drug efficacy and toxicity are linked, in many cases, to single nucleotide polymorphisms (SNPs) in genes coding for drug metabolising enzymes and transporters. Taxanes are active for several tumour types, including breast cancer. But this is limited by adverse events such as neurotoxicity and haematological toxicity.

Purpose To evaluate the associations between a panel of 92 SNPs in 33 genes and adverse events developed by breast cancer patients treated with taxanes.

Materials and Methods Between June 2011 and May 2012 breast cancer patients treated with taxanes who gave informed consent were genotyped for 92 SNPs in 33 genes. Genomic DNA was analysed by a genetic analysis platform (MassArray, Sequenom). HardyWeinberg equilibrium was assessed. Clinical data were recorded. The association between genotypes and adverse reactions was assessed with Fisher's exact test and X2-test.

Results Sixty-seven Caucasian women (mean age: 53 years old; $95 \% \mathrm{CI}=49-56$ ) were genotyped. All genotype frequencies were in Hardy-Weinberg equilibrium. $53.7 \%(n=36)$ of the patients were treated with docetaxel and $46.3 \%(n=31)$ with paclitaxel. Histotypes: $88.1 \%(n=59)$ ductal, $7.5 \%(n=5)$ lobular and $4.5 \%(n=3)$ other. Significant associations were found between: A) Overall grade III-IV toxicity: TP53 rs 1045522 [10.8\% $(\mathrm{n}=4) \mathrm{GG}$ vs. $43.3 \%$ $(\mathrm{n}=13) \mathrm{GC} / \mathrm{CC}, \mathrm{p}=0.004]$; DNA repair gene XPC rs2228001 [8.7\% $(\mathrm{n}=2)$ AA vs. $34.1 \%(\mathrm{n}=15)$ AC/CC, $\mathrm{p}=0.037] . \mathrm{B})$ Anaemia grade II-IV: ERCC2 rs 1799793 [7.1\% $(\mathrm{n}=2)$ GG vs. 33.3\% $(\mathrm{n}=13)$ GA/AA, $p=0.016] ;$ XPC rs 2228001 [4.3\% $(n=1)$ AA vs. 31.8\% ( $n=$ 14) $\mathrm{AC} / \mathrm{CC}, \mathrm{p}=0.012]$. C) Neutropenia grade II-IV: CYP2C8 rs1341164 [6.5\% ( $\mathrm{n}=2)$ TT vs. $27.8 \%(\mathrm{n}=10)$ TC/CC, $\mathrm{p}=0.028]$; TP53 rs 1045522 [8.1\% (n=3) GG vs. $30.0 \%(\mathrm{n}=9) \mathrm{GC} / \mathrm{CC}$, $\mathrm{p}=0.027$ ] XPC rs2228001 [0.0\% AA vs. $27.3 \%(\mathrm{n}=12) \mathrm{AC} / \mathrm{CC}$, $\mathrm{p}=0.006]$. D) Diarrhoea grade II-IV: $A B C B 1$ rs1128503 [21.4\% $(\mathrm{n}=6)$ TT vs. $2.6 \%(\mathrm{n}=1) \mathrm{TC} / \mathrm{CC}, \mathrm{p}=0.018]$; CYP1B1 rs72549389 $[20.0 \%(n=7)$ TT vs. $0 \%$ TG/GG, $p=0.014]$. No associations with neurotoxicity were found.

Conclusions Studying genetic variations can help to identify patients at higher risk of suffering adverse events and provides useful information to individualise therapy.

No conflict of interest.

\section{PHC-026 TACROLIMUS AND IMATINIB INTERACTION. A CASE STUDY}

doi:10.1136/ejhpharm-2013-000276.371

P Selvi-Sabater, AM Rizo-Cerda, B Arribas-Diaz, A Morego-Soler, A Bosó-Ribelles, 'MC Sánchez-Mulero, I Sánchez-Martinez, N Manresa-Ramón, A Espuny Miro, C CastillaLlorente. Hospital Morales Meseguer, Pharmacy, Murcia, Spain

Background Tacrolimus is a drug metabolised by CYP3A4. Since imatinib increases the plasma concentrations of simvastatin, a CYP3A4 substrate, this indicates that it is an inhibitor of this enzyme and may affect other drugs.

Purpose To describe the possible interaction between imatinib and tacrolimus that result in increased blood levels of Tacrolimus.

Materials and Methods Information was collected through the SAVAC and SELENE computer systems and reviewing patient history. The variables compiled were tacrolimus blood levels, dose and dose regimen.

Results The patient had an allogeneic blood stem cells transplant from an unrelated donor, HLA and $\mathrm{ABO}$ compatible, presenting cutaneous sclerodermiform graft versus host disease (GVHD) on tacrolimus $(2 \mathrm{mg} / 12 \mathrm{~h}$ ) treatment and blood levels around $4 \mathrm{ng} / \mathrm{ml}$ for 12 weeks. After starting treatment with imatinib, in the following five tests tacrolimus levels ranged from $5.8 \mathrm{ng} / \mathrm{ml}$ to $8.9 \mathrm{ng} / \mathrm{ml}$ with no change in the dose of tacrolimus. After 45 days of treatment imatinib was suspended and tacrolimus levels recorded in the following test after discontinuation of imatinib fell to around $4 \mathrm{ng} / \mathrm{ml}$. Conclusions The increase in tacrolimus blood levels, without changing the dose, supports the possible interaction between imatinib and tacrolimus.

No conflict of interest.

\section{PHC-027 THE PHARMACIST'S ROLE IN IMPROVING VALPROIC ACID PRESCRIPTIONS}

doi:10.1136/ejhpharm-2013-000276.372

B San José, Z Baskaran, I Bilbao, A De Basagoiti, A Belaustegi, J Hernández, S Sautua M Castaño, A Bustinza, MA Gil. Hospital de Cruces, Servicio de Farmacia, Barakaldo, Spain

Background Valproic acid (VPA) is $90-95 \%$ protein bound to albumin; this binding can be saturated so other parameters that can modify the free fraction of VPA should be taken into account.

Purpose To identify areas for improvement in VPA use and monitoring in a tertiary hospital where the pharmacy service does not routinely send pharmacokinetic dose adjustment recommendations. 